https://doi.org/10.18485/slav_markovic_slobodan.2018.ch8 821.163.4.09"1918/1940" Марковић, Слободан Ж.

\author{
ЛИДИЈА Р. ТОМИћ* \\ Универзитет Црне Горе \\ Филолошки факултет, Никшић
}

\title{
КЊИГА КЊИЖЕВНИ ПОКРЕТИ И ТОКОВИ ИЗМЕБУ ДВА СВЕТСКА РАТА ИЛИ НАУЧНИ МЕТОДИ ПРОФ. ДР СЛОБОДАНА Ж. МАРКОВИЋА
}

\begin{abstract}
У раду се разматра научни приступ проф. др Слободана Марковића у проучавању књижевности између два свјетска рата на јужнословенском простору. Ријеч је о Марковићевој репрезентативној књизи Књижевни йокретии и йокови

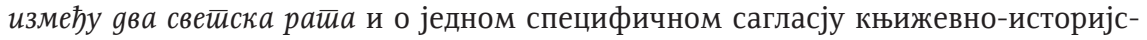
ке и друштвене перспективе тумачења, с увијек присутном свијешћу о значају књижевних идеја и вриједности, и у српској, и у другим југословенским књижевностима.

Кљуине ријечи: међуратна књижевност, експресионизам (модернизам), надреализам, социјална књижевност, дјечија књижевност, часописи, поетичке идеје, књижевни токови.
\end{abstract}

Посвећеност проф. др Слободана Марковића проучавању међуратне књижевности односи се на цјеловити пресјек најважнијих догађаја и феномена овог историјски омеђеног, а поетички разуђеног доба на југословенском простору. Методологијом прегледног и обухватног уочавања и навођења најважнијих особина међуратне књижевности, аутор проф. др Слободан Марковић, седамдесетих година 20. вијека, књигом

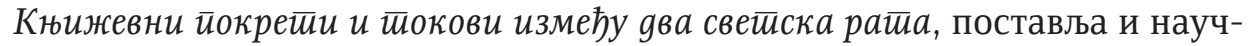
но аргументује токове овог књижевног периода.

Зрелошћу искусног аналитичара, Слободан Марковић прво полази од друштвеног контекста, настанка и развоја књижевних покрета. Загледан у историјске процесе, у однос националних књижевности и идеје југословенске књижевности, од посебности до кохерентности, Марковић анализира динамичност међусобних односа на основу појединачних књижевних и културних чињеница тог времена. Тим начином, Марковић доводи у везу друштвено вријеме, националне књижевности и њихове додирне тачке, својствене квалификовању општих

*lidija.tomicpg@gmail.com 
особина стваралачког процеса. Говорећи о међуратној књижевности или књижевности између два рата, он спецификује област у којој су од значаја књижевна одређења књижевних токова. Без намјере да дијели, Марковић уочава да је сложеност националног питања књижевности у југословенској заједници подређена важности епохе која националне књижевности посматра у односу на програмска и друга прожимања и утицаје.

Професор Марковић у својој књизи има у виду два аспекта проучавања: дедуктивним методом слиједи фазе књижевног развоја, а индуктивним - заједничке појаве у југословенској, свесловенској и свјетској књижевности. Професор уочава потенцијале националних књижевности и култура, „које су се”, како каже, „испољиле не само у друштвеној основи дела, већ и у идејним и естетским стремљењима и остварењима писаца” (Марковић 1970: 9). Марковић не мисли да постоји „строго поистовећивање етапа књижевног развоја са историјским временским раздобљима" (1970: 9), али је увјерен да су се границе јужнословенских народа између два рата помјериле токовима „националног, културног и уметничког развоја”, кроз однос који упућује „једне на друге - било на сарадњу или на отпоре" (1970: 10). Марковић исцрпно указује на специфичности „литерарних појава”, „књижевних покрета”, „места писаца и њихових дела", руководећи се условљеношћу питања шта из чега происходи. Позива се на мисао Волфганга Кајзера да „наука о књижевности мора прећи националне оквире" (Марковић 1970: 10 и 18) да би историју националних књижевних токова посматрао у оквиру „заједничког имена за збир националних литература Срба, Хрвата, Словенаца, Македонаца, Црногораца и Муслимана” или „извесних блиских одлика које се могу назвати заједничким именом југословенске" (1970: 10).

Национална обиљежја јужнословенских књижевности - језик, етничко биће и историјски идентитет, подразумијевају национална одређења књижевности, али се у оквиру књижевних покрета даје предност умјетничкој и естетској страни стваралаштва. Марковић говори о токовима међуратне књижевности, њиховом статусу у књижевном изразу и особености. Тим ставом, проф. др Слободан Марковић доводи у везу традицију и садашњи тренутак, разумијевање књижевног наслеђа и вријеме новина у књижевном стваралаштву. Логиком књижевног прегледа, Марковић тумачи особине књижевних токова, њихову комуникацију, као и однос стилских формација. Професор Марковић указује на чињеницу да се „књижевни период не поистовећује са литерарним правцима”, већ с укупношћу „дела која су идејно и стилски подударна" (1970: 11). 


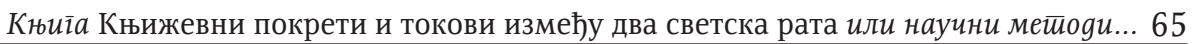

Слободан Марковић констатује да међуратна књижевност није једнолична ни шаблонска, да је идејно и стилски различита, али и цјеловита у формату овог периода: „Може се рећи да се међуратни период развоја књижевности ипак издваја и одликује као једна карактеристична развојна етапа у којој се јавља низ литерарних покрета и струјања, који у таквом виду деловања и организованости нису били познати ни пре ни касније у нашој књижевности" (1970: 11). Показатељи приближавања „појединих југословенских литература” су часописи Књижевни jȳ (1918-1919), Зенити (1921), Дан (1919-1920) и интегративна концепција „југословенства и у књижевности". Интенције заједништва се диференцирају према књижевним срединама и њиховим гласилима, која, опет, окупљају писце и дјела ширег југословенског простора ${ }^{1}$. Смисао Марковићевог проучавања међуратне књижевности јесте да у искуствима књижевних оријентација, стваралачких идеја и исказивања, пронађе дијалог, а не облике књижевних искључивости и сукоба.

Та дијалошка компонента проучавања говори и о духу Марковићевих компаративних анализа, о природи хуманистички отворених анализа, о увијек присутном разумијевању додира, али и разлога спорења и неслагања. Његова анализа иде за ширином погледа на књижевне садржаје, тематске и стилске компоненте више жанровски различитих текстова. Из поштовања књижевне традиције и поштовања нових облика књижевног стваралаштва, Марковићева мисао о међуратној књижевности отвара просторе књижевних утицаја и повезивања са словенском, европском и свјетском књижевношћу. У динамичној разноврсности књижевних токова види разлику, а у разлици сродност због које су тешко одредиве границе међуратне књижевности. Ипак, формацијска усредсређеност на три тока међуратне књижевности сигнализује области изучавања експресионизма (модернизма), надреализма, социјалне литературе. Особеност три начина стваралаштва карактерише вишезначност у модернистичкој иновативности, али и у друштвеној функцији књижевности и њеној стилској актуелности и специфичности.

Марковић и поставља и разрешава питања развоја међуратне књижевности. У различитости књижевних програма и оријентација, он анализира обликовне моделе књижевних поступака. Указује на отклон од традиционализма и потребу да се претходни поетички системи замијене новим. За Марковића су поетичке промјене, „књижевна гибања”, „преплитања”, „комешања”, „превратничка кретања”, видови дисконтинуитета, али и специфичне новине које покрећу вриједносна питања - ко-

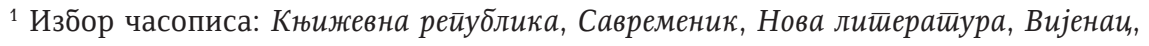

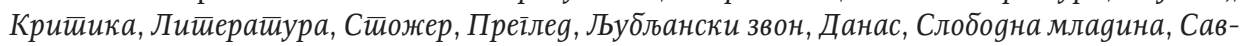

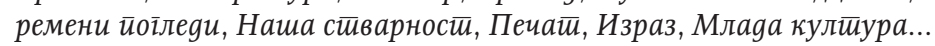


лико је неки правац нов и колико „испољених чинилаца” даје одговор на питање о блискостима или разликама између стилских формација, њихових особина и стваралачких доприноса.

У посебним поглављима, Марковић разматра особине књижевних покрета. Прво говори о експресионизму као о поетској побуни и ослобађању унутрашњих садржаја. Полази од сазнања о настанку покрета и особина литературе која почива на интензитету лирских распростирања: од програмских до појединачних видова исказивања, заснованих на екстазама и крику антиратних расположења, на одрицању од поетског склада и хармоније. Професор Марковић открива њемачки утицај на експресионистичке токове, концепције књижевних програма, часописе, карактеристичне појаве, какве су имали њемачки и југословенски аутори - теоретичари књижевности, писци, пјесници... Модернизам књижевних испољавања и литерарних облика учинио је разноврсним „литерарна настојања писаца или групе стваралаца" (1970: 32). Однос „поетских садржина" и формалних карактеристика у стваралаштву Милоша Црњанског, Станислава Винавера, Сибе Миличића, Тодора Манојловића, Светислава Стефановића, Растка Петровића, Драгана Алексића, Љубомира Мицића, Бошка Токина, Риста Ратковића, Рада Драинца, посредно је дат у објашњењима књижевних феномена, карактеристичних експресионистичких појава, група („Група уметника”), ревија („Бела ревија"), једном ријечју, књижевних збивања и обједињених новина - носилаца експресионистичког гласа и смисла књижевног покрета, видљивог, нпр., у дјелатности „Библиотеке Албатрос”, групи „Аlpha”, активизму програмских идеја, на југословенском, и доминантнијем, „београдском” или „српском" простору експресионизма, који укључује „повезаност литерарног развоја код Срба са општим књижевним кретањима код осталих Југословена и у свету" (1970: 38). Професор Марковић тежи да аргументује казивање о почецима и развоју експресионизма, да изведе најважније моменте и на основу њих закључи да различитост националних књижевности у експресионизму улази у епоху „стилске блискости” (1970: 40). Словеначки, хрватски и српски експресионизам, сматра Марковић, дио су „истородних својстава која се могу извући и уопштити из индивидуалних творевина" (1970: 41). Он, с правом, закључује да је експресионизам израз поетских трагања за новим изразом, да је антиратним расположењем и ширином експресије испунио не само индивидуалну, и националну, већ и интернационалну димензију: „У југословенском случају, нашли су се у истом покрету писци образовани у различитим литерарним школама, било да су изашли из словеначке и хрватске Модерне или из српске Декадансе, било да су их напајали на развијенијим француским и немачким књижевнотеоријским и стваралачким изворима" (1970: 41). Методом рашчлањивања, сасвим егзактно, с елементима 
књижевноумјетничке условљености, професор Марковић градира приоритете који су одредили „експресионистички путоказ”. Први се тиче „сфера духа" и савременог човјека, други - „промена и изграђивања поетског израза", а трећи - сасвим конкретизоване релације „социјалног” и „националног” својства постојања. Он сматра да се својства експресионизма тичу и односа космичких, хришћанских, религијских и етеричних садржаја, утопијских, артистичких, покретачких, оних који помажу људима „да се ослободе стега и да пронађу своје песничко Ја" (1970: 44). Марковић види поетску енергију бића у експресионистичком оквиру. Теоријска димензија поетских новина увијек је у његовом тумачењу освијетљена књижевноисторијским спектром питања, уз позивање на научно важна одређења експресионистичких поетика.

Експресионистички путеви имају своје смјерове и Марковић их региструје и означава, верификује и објашњава - „Све видније испољавање разлика у друштвено идејном ставу писаца продубљивало је нејединствености и противуречности које је експресионизам од почетка носио у себи и наговештавало је блиски крај покрета" (1970: 47).

Његово тумачење експресионизма сумира „идејне, тематске и изражајне" карактеристике поетских токова, увијек у његовој анализи окренутих условима из којих су проистекли и у којима су се јавили и у трајању мијењали.

У поглављу „Београдски надреализам”, Марковић поступно објашњава почетке јављања надреализма, његовог имена и настанка, опредјељујућих момената и особина развоја. Марковић и овдје слиједи друштвене и егзистенцијалне просторе „свесног и несвесног постојања” (1970: 55), једну врсту модерних „схватања и стремљења” у трећој деценији двадесетог вијека. У времену хетерогених „изама”, и сасвим сведено презентованих особина дадаизма, до надреализма као покрета аутор долази еволутивно, од утицаја француских надреалиста до „југословенске” и „београдске” сцене надреалистичких токова. Он компаративно анализира идеје и схватања надреализма, као и „начела на којима се изграђивао надреалистички метод стварања" (1970: 61). Марковић говори о формирању београдског надреализма и његовом односу према француском надреализму, уважавајући експресионизам као претходницу надреализма. За часопис Свеgочансшива, у којем је објављен Ристићев текст о надреализму, каже да је имао „експресионистичку физиономију”, да су Пуйеви окупљали „најсмелије експериментаторе и истраживаче”, а да су Милан Дединац, Растко Петровић, Душан Матић, Александар Вучо и Марко Ристић били модернисти с „најновијим видицима савремене уметности" (1970: 63). Епоху модернизма конкретизује чињеницама о књижевним објавама модернизма и надреализма у часописима, у 
поетским текстовима, у појави алманаха Немогууће и његовој објави надреализма. Марковић иде за суштином надреалистичког покрета, за издањима надреалистичких текстова, за границама поетских трагања које не одваја од експресионистичких, све до тренутка када се симболика „немогућег” односи на надреалистички проседе подсвјесног или аутоматизам подсвијести. Надреалистичка издања, настала у коауторству Коче Поповића, Марка Ристића, Давича, Костића, Матића, Живадиновић Бора и М. Ристића, синтетизовала су идеје и начела надреализма, све до неколико бројева публикације Наgреализам gанас и овgе, који је, парадоксално, значио „слом надреалистичког покрета” (1970: 70).

Покрет који ставља акценат на „колективистички дух стварања” (1970: 73) није изградио „целовиту поетику”, већ систем надреалистичких дјелатности, „без јасног друштвеног идеала” (1970: 76), који је, сматра Марковић, предуслов за „наглашавање конкретног друштвеног става”. А он се односи на услов надреалистичке енергије и садржаје књижевне стварности који су били супротни спољашњем, социјалном амбијенту борбе за утицај књижевности и умјетности на друштвени живот.

Већ у овом поглављу, Марковић говори о покрету социјалне књижевности, и о финесама надреализма, који „и поред разлика у друштвено естетским погледима ове две књижевне струје имају и неке додирне тачке, првенствено у своме друштвеном ставу" (1970: 77).

Аналитички, прегледно и исцрпно, Марковић у тумачењу не изоставља ни политичке утицаје „по питањима књижевности, умјетности, културе и критике" (1970: 85). Марковић кристализује анализу јасним закључцима који кажу да је „надреализам превасходно дао теоријске резултате који ће остати трајно присутни у развоју уметности" (1970: 84) и, с друге стране, историјски оправданим разлозима који објашњавају раслојавање покрета и идејно размимоилажење надреалиста. Он синтетизује и истиче програмска начела и доследност мање групе надреалиста у односу на припаднике надреалистичког покрета преусмјеравају надреалистичку активност у другом правцу. Из ширине прегледа, Марковић апострофира заслуге и вриједности надреализма, посебно, значај „нових поетских подручја, подстицаја и изражајних могућности” (1970: 89), које ће „посредно и непосредно утицати на токове наше поезије" (1970: 90). Особине надреалистичке херметичности, сматра он, припадају пјесничким категоријама које су допринијеле умјетничким вриједностима касније пјесничке традиције.

У поглављу „Покрет социјалне књижевности”, као и у претходним поглављима о експресионизму и надреализму, Марковићева научна аргументација отвара простор за рекапитулацију појма ангажоване књижевности, његову примјенљивост и на писце који то формацијски нијесу, а који, због изразитости неког својства, може бити укључен у спектар 
„борбеног”, „бунтовног”, „духовног” и „социјалног” одредишта мотива у лирици, прози, роману. Друштвени моменат је, сматра он, у најближој спрези с идејом социјалне литературе, при чему се програмска енергија надреалистичке „акционо-превратничке” побуне окренула животу, „са идејних позиција које наговештавају нужну промену друштвеног система као предуслова за решења многих социјалних питања и за побољшање човекових егзистенцијалних прилика" (1970: 96).

Руководећи се развојем социјалне књижевности, професор Марковић налази њене елементе у експресионизму, „на терену реалности где им је људска неравноправност била најпријемчивија као мотивско подручје” (1970: 97), као и у надреалистичким негацијама „утврђених норми и конвенција грађанског друштва" и у заједништву какво је у Кюизи gруіоова: алманаху најмлађих јуіословенских соиијалних лиричаpa (1970: 98). Марковић слиједи развој покрета социјалне књижевности, однос друштвене свијести и естетске улоге књижевности у животу друштва.

Идеолошка и идејна структура покрета социјалне књижевности сагледана је у дејству и утицајима књижевних часописа, издавачких програма, критичких погледа, ставова комуниста, марксиста, „културних радника”, окупљених око „Нолита”: „Ото и Павле Бихаљи, Отокар Кершовани, Хуго Клајн, Веселин Маслеша, Мила Димић, Јосип Кулунџић, Јован Поповић, Велибор Глигорић и, касније, Милан Богдановић, Густав Крклец, Богомир Херман и други” (1970: 109), потом „напредних писаца”, „као што су Павле Бихаљи, Стеван Галогажа, Миле Клопчић, Јован Поповић, Кочо Рацин и други [...]" (1970: 113), важних докумената, политичких ситуација и одлука, једном ријечју, најважнијих момената књижевног живота. Идејну слику прати књижевнотеоријска мисао, као и становишта о тематским и изражајним могућностима социјалне књижевности. Обухватно, с аргументима и књижевноисторијским чињеницама, региструје прелазак надреалиста, Александра Вуча, Милана Дединца, Душана Матића, Ђорђа Јовановића и Оскара Давича, у активизам социјалне провенијенције. Марковић говори о фазама и интензитету социјалне књижевности, о идеји „подруштвљавања” и „актуализације” књижевности у друштвеним приликама. Говори о критици, која верификује интензитет друштвености, о утицају и вези са совјетским соцреалистичким тековинама новог реализма, термина који се јавља као синоним социјално одређујућем спектру књижевних тема и мотива. Марковић у свој књижевноисторијски преглед укључује и питања субјективности, и питања тенденције у књижевности, разматра однос животно реалног и психолошки мотивисаног збивања: „Да би се продрло и зашло у суштину друштвене стварности, коју уметник има првенствено на уму, не залази се у детаљистичко рашчлањивање ликова, стања и појава, али 
су избегнути и натуралистички описи у широким потезима" (Марковић 1970: 118). Говори о стилу, језику, лексичком фонду („горковска лексичка и стилска девиза - да језик мора бити јасан, прецизан и оштар", 1970: 119). Не изоставља ни „марксистичку идеолошку основу” у филозофији, политици, журналистици, умјетности, у поезији.

Професор Марковић нијансира и наглашава стање једног времена, утицај политике на књижевност и њен развој, налазећи простор и за „вредна литерарна дела, као што су приповетке Јована Поповића, Чедомира Миндеровића, Мишка Крањеца и Прежихова Воранца; романе Милке Жицине, песме Чедомира Миндеровића, Радована Зоговића, Јована Поповића, Милана Дединца, Тонета Селишкара, Коче Рацина и других" (1970: 124).

У четвртом поглављу књиге Кюижевни йокрейи и йокови између

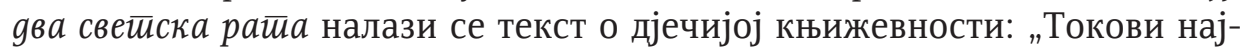
новије књижевности за децу". Ријеч је о есеју у којем професор Марковић говори о поетичким одређењима књижевности за дјецу, о схватању дјечијег свијета у литератури која у раном узрасту развија смисао за етички вриједна стања хумане егзистенције. Тема дјетињства, игре, дјечијег свијета и свијета одраслих отварају питања игре и искуства живота, примијењена на вриједност дјечијих емоција, фантазије и реалности. Професор Марковић анализира дјела Александра Вуча, Сан и јава храб-

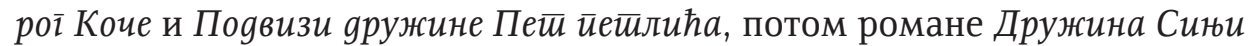
іалеб Тона Селишкара, Дружба Пере Квржище Мата Ловрака. Указује на специфичност „приказивања живота деце и одраслих у рату” (1970: 134) у дјелу Бранка Ћопића и других аутора, на измијењен однос према личности дјетета у дјелу Душана Радовића, Григора Витеза итд. Марковић вјерује у свијет дјетета и у вриједности литературе за дјецу, која његује и развија не само свијет дјетета већ и свијет књижевног простора који не дијели садржаје за дјецу и одрасле.

Увид у једну књигу проф. др Марковића показује да је начин проучавања књижевних покрета и токова у књижевности између два рата у складу с непосредношћу књижевноисторијског увида и описа не само хронологије покрета већ и њиховог развоја, који укључује прегледност, аналитичност, поступност, коначно, систематичност, из којих се гранају правци професорових научних и стручних тумачења. Напомена аутора, на крају књиге, да је „аутор изучавао књижевне појаве имајући у виду првенствено дубину њиховог рефлектовања у српској књижевности" и да је „настојао да сагледа њихово испољавање и повезаност са токовима у књижевностима осталих југословенских народа и у светској књижевности" (1970: 142), говори о методологији Марковићевих проучавања - повезивању појединачног и општег, националног и интернационалног 


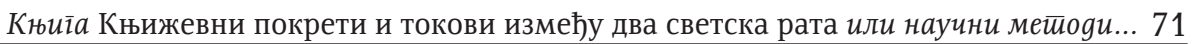

у непосредном и компаративном, боље рећи, књижевно отвореном и комуникативном односу историје и књижевности, књижевности и умјетности, унутрашњих и спољашњих утицаја и односа.

У том смислу, професор Марковић је отварао питања књижевног развоја и рјешавао их посвећеним односом према књижевним чињеницама, које су увијек биле полазиште његове књижевнотеоријске аргументације.

\section{Литература}

Марковић 1970: S. Marković, Književni pokreti i tokovi između dva svetska rata, Beograd: Književni klub Obelisk.

Лидия Р. Томич

\section{КНИГА «ЛИТЕРАТУРНЫЕ ДВИЖЕНИЯ И ТЕЧЕНИЯ МЕЖДУ ДВУМЯ МИРОВЫМИ ВОЙНАМИ» ИЛИ НАУЧНЫЕ МЕТОДЫ ПРОФЕССОРА Д-Р СЛОБОДАНА Ж. МАРКОВИЧА}

\section{Резюме}

Если посмотреть книгу «Литературные движения и течения между двумя мировыми войнами» профессора д-р Слободана Марковича, станет ясно, что речь идет о фундаментальном типе исследования, о поэтапном и объединяющем толковании межвоенного периода в сербской и других южнославянских литературах. Профессор Маркович указывает на эволютивное развитие и генезис литературных движений, на обусловенность и свойства модернистских и других течений межвоенной литературы. Он следует отношению поэтических идей, развитию и структуре национальных литератур того времени с идеей связать сербскую и другие литературные традиции с сопоставительными аспектами мировой литературы.

Ключевые слова: межвоенная литература, экспрессионизм (модернизм), надреализм, социальная литература, детская литература, журналы, поэтические идеи, литературные течения 